\title{
Genetic variability in four samples of Neoplecostomus yapo (Teleostei: Loricariidae) from the rio Paranapanema basin, Brazil
}

\author{
Juliana S. Philippsen ${ }^{1}$, Erasmo Renesto ${ }^{1}$, Ana Maria Gealh ${ }^{2}$, Roberto F. Artoni², \\ Oscar A. Shibatta ${ }^{3}$ and Claudio H. Zawadzki ${ }^{1}$
}

Four samples of Neoplecostomus yapo were analyzed through the allozyme electrophoresis technique in corn starch gel. The allozyme pattern was similar to those found in N. paranensis with 24 loci scored. Two samples (ribeirão Atlântico and ribeirão Uraí) showed monomorphic bands for all 24 loci, whereas the other two (rio Verde and rio Fortaleza) showed 8.3\% of polymorphic loci. The $H$ e genetic variability estimates for the rios Verde and Fortaleza populations were 0.0195 and 0.0179 , respectively, too much inferior to the mean heterozygosity summed to species from the whole world $(0.051)$. The Wright statistical values $F_{\text {IS }}=$ $0.5181, F_{\mathrm{IT}}=0.5681$ and $F_{\mathrm{ST}}=0.1039$ and the genetic distance of Nei values showed that the four samples are genetically very similar to each other and that there is homozygote excess in the polymorphic loci.

Foram analisadas quatro populações de Neoplecostomus yapo por meio da técnica de eletroforese de aloenzimas em gel de amido de milho. O padrão de bandas obtido foi semelhante ao de $N$. paranensis, tendo sido detectado um total de 24 loci enzimáticos. Duas populações (ribeirão Atlântico e ribeirão Uraí) apresentaram formas monomórficas para todos os 24 loci, enquanto as outras duas (rio Verde e rio Fortaleza) apresentaram $8,3 \%$ de loci polimórficos. As estimativas de variabilidade genética $H$ e para as populações dos rios Verde e Fortaleza foram 0,0195 e 0,0179 , respectivamente, muito inferiores à média das espécies de peixes no mundo todo $(0,051)$. Os valores das estatísticas de Wright $F_{\mathrm{IS}}=0,5181, F_{\mathrm{IT}}=0,5681 \mathrm{e} F_{\mathrm{ST}}=0,1039$ e os valores de distância genética de Nei mostram que as quatro populações são geneticamente muito semelhantes entre si e que há excesso de homozigotos nos loci polimórficos.

Key words: Allozymes, Genetic variation, Neoplecostominae, Neotropical fishes, Siluriformes.

\section{Introduction}

Neoplecostomus paranensis, diagnosed by the absence or reduction of adipose fin, was the only species of the genus to the upper rio Paraná basin, until recently. Currently, new survey efforts in streams from this basin allowed the collection and deposit of several Neoplecostomus specimens in institutional collections. Some of these specimens contrasted to $N$. paranensis by the presence of a well-developed adipose fin. Based on this material, Zawadzki et al. (2008a) described Neoplecostomus yapo, from riacho Fortaleza, rio Tibagi ba$\sin$. However, in a morphological investigation where the spe- cies number in one lot sometimes is not enough to a suitable analysis, one could question if this character is robust enough to diagnose species of this genus. Besides, Langeani (1990) highlighted that the species of Neoplecostomus are very similar to each other and there are few useful characters to diagnose them.

In systematics, the allozyme electrophoresis technique is useful in the detection of gene flow restriction among morphologically similar species. This technique has been taken for a long time as a good tool for solving taxonomic problems (Buth, 1984; Zawadzki, 2001).

In the neotropical region, few taxonomic studies may be

\footnotetext{
${ }^{1}$ Universidade Estadual de Maringá, Departamento de Biologia, Núcleo de Pesquisas em Limnologia, Ictiologia e Aqüicultura G-90, Av. Colombo, 5790,87020-900 Maringá, PR, Brazil.ju_strieder@yahoo.com.br; erenesto@nupelia.uem.br; chzawadzki@hotmail.com. Send reprint requests to $\mathrm{CHZ}$.

${ }^{2}$ Universidade Estadual de Ponta Grossa, Departamento de Biologia Estrutural, Molecular e Genética, Av. Carlos Cavalcanti, 4748, 84030900 Ponta Grossa, PR, Brazil. anagealh@uol.com.br; rfartoni@uepg.br

${ }^{3}$ Universidade Estadual de Londrina, Departamento de Biologia Animal e Vegetal, Rodovia Celso Garcia Cid PR-445, Km 380, 86051-990 Londrina, PR, Brazil.shibatta@uel.br
} 
related to allozymic data despite its usefulness has been attested to the systematic studies of fish in the genera Astyanax (Renesto \& Zawadzki, 1997), Pimelodus (Almeida \& Sodré, 1998; Renesto et al., 2000), Crenicichla (Renesto et al., 2001), Hoplias (Peres et al., 2002) and especially for the family Loricariidae (Zawadzki et al., 1999; 2000; 2001; 2002; 2004b; 2005 and Paiva et al., 2005). Fisch-Muller et al. (2001) diagnosed and described two new cryptic species of Ancistrus from the upper rio Tocantins basin obtaining four diagnostic loci of the ten examined. More specifically, allozymic studies have proved to be effective in the discrimination of species of the family Loricariidae. Zawadzki et al. (1999) discriminated three species of the genus Hypostomus from the rio Iguaçu, $H$. derbyi, $H$. myersi and $H$. aff. commersoni, associating allozyme and multivariate morphometric techniques. Zawadzki et al. (2000) found allozymic markers as satisfactory as the morphologic ones obtained by Reis \& Pereira (2000) in the discrimination of three species of the genus Loricariichthys from southern Brazil.

Zawadzki (2001) diagnosed through allozyme electrophoresis ten species of Hypostomus from the rio Corumbá, rio Paranaíba basin, $H$. ancistroides, $H$. margaritifer, $H$. regani and seven presumptive new species. Soon after, two of these new species were formally described as $H$. denticulatus and $H$. heraldoi by Zawadzki et al. (2008c). Zawadzki et al. (2005) based on allozymes also detected 11 genetically distinct species from Itaipu reservoir, $H$. albopunctatus, $H$. ancistroides, $H$. commersoni, $H$. aff. derbyi, $H$. margaritifer, H. microstomus, $H$. regani, H. ternetzi, Hypostomus sp. 1, Hypostomus sp. 2 and Hypostomus sp. 3.

Sometimes, species can be morphologically very similar to each other, but genetically much different. Zawadzki et al. (2004a), using allozyme electrophoresis compared Neoplecostomus sp. (= N. corumba) from the rio Corumbá, rio Paranaíba basin to $N$. paranensis from córrego Hortelã, rio Paranapanema basin and, despite general morphological similarity, these populations showed as high genetic distance as to species pertaining to different genera in studies on other Loricariidae fishes by Zawadzki et al. (2005). From the 22 surveyed loci obtained by Zawadzki et al. (2004a), 12 were diagnostic. Thus, a high genetic diversity could be hided behind an apparent morphological uniformity of the Neoplecostomus samples from the upper rio Paraná basin. Zawadzki et al. (2004a) also found a zero genetic heterozygosity (all homozygous to the same locus in the sample) to the $N$. paranensis sample. These findings, usually indicates small population number, restrict geographical distribution, as well as restrict gene flow to some other neighbor populations. Reduction in gene flow and endogamic events are population factors favoring endemism and high speciation taxes.

This work aims to analyze through allozyme electrophoresis technique, four samples of $N$. yapo from streams of the rio Paranapanema basin. This analysis intends to generate data about the genetic structure of these samples, and data about the genetic variability of these samples.

\section{Material and Methods}

From November 2006 to December 2007 specimens of four samples of Neoplecostomus yapo were collected. The fishes were from ribeirão Atlântico, tributary to rio Pirapó and located at município de Mandaguaçu; rio Verde, tributary to rio Tibagi, município de Ponta Grossa; rio Fortaleza, tributary to rio Tibagi, município de Tibagi; and ribeirão Uraí, tributary to rio Tibagi, município de Londrina, all in the rio Paranapanema basin, State of Paraná (Figure 1).

Samples from the ribeirão Atlântico $\left(23^{\circ} 18^{\prime} 11^{\prime \prime} \mathrm{S} /\right.$ $\left.52^{\circ} 01 ' 54^{\prime \prime} \mathrm{W}\right)$, NUP 5156, 15 specimens; rio Fortaleza $\left(24^{\circ} 25^{\prime} 30^{\prime \prime} \mathrm{S} / 50^{\circ} 13^{\prime} 55^{\prime} \mathrm{W}\right)$, NUP 3560,30 ; ribeirão Uraí ( $\left.23^{\circ} 28^{\prime} 04^{\prime \prime} \mathrm{S} / 51^{\circ} 18^{\prime} 54^{\prime \prime} \mathrm{W}\right), \mathrm{NUP} 4747,15$; rio Verde $\left(25^{\circ} 04^{\prime} 81^{\prime \prime} \mathrm{S} /\right.$ $50^{\circ} 04^{\prime} 03^{\prime}$ 'W), NUP 5156,15 , were used to allozyme electrophoresis and voucher specimens were deposited in the collection of fishes of the Nupélia (Núcleo de Pesquisas em Limnologia, Ictiologia e Aqüicultura) from the Universidade Estadual de Maringá (NUP). One specimen of each sample is represented in lateral view in Figure 2. Fish were collected under license of the Instituto Brasileiro do Meio Ambiente e dos Recursos Naturais Renováveis (IBAMA), protocol number 11360-1.

The specimens were collected and conserved whole in liquid nitrogen at State University of Maringá, Maringá, Paraná State. The muscle, liver, eye, stomach, heart, kidney and gill tissue samples were homogenized with a plastic stick in propylene tubes $(1.5 \mathrm{ml})$ with $100 \mu \mathrm{L}$ of Tris- $\mathrm{HCl} 0.02 \mathrm{M}$, pH 7.5 buffer. Due to the presence of a great amount of fat in the liver, $100 \mu \mathrm{L}$ of carbon tetrachloride $\left(\mathrm{CCl}_{4}\right)$ was added to the tube (Pasteur et al., 1988). The homogenized samples were centrifuged at 18,000 rpm for $30 \mathrm{~min}$ at temperatures between $1^{\circ}$ and $5{ }^{\circ} \mathrm{C}$. The enzyme supernatant extract was applied to

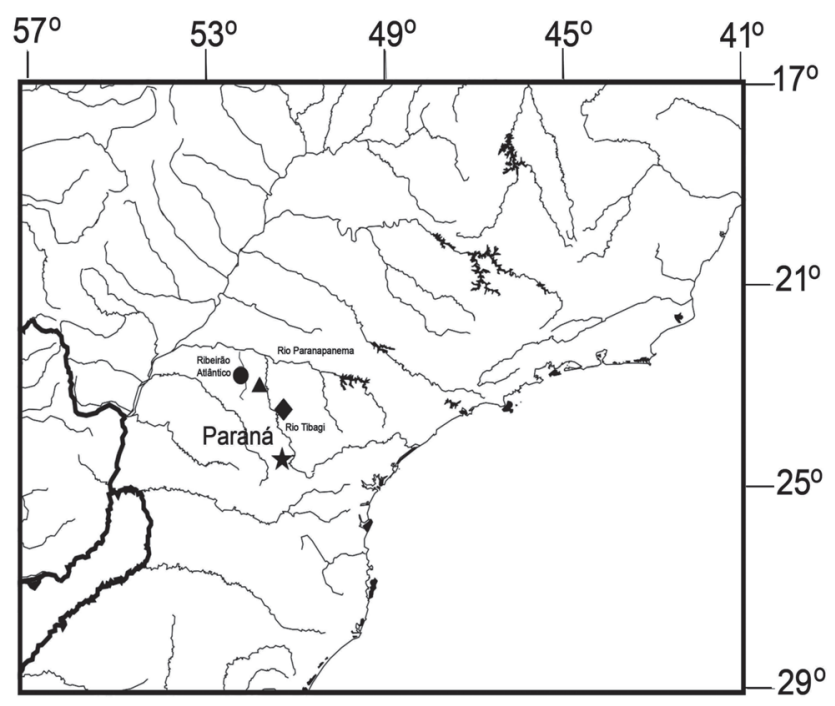

Fig. 1. Partial map of South America showing the collecting sites of Neoplecostomus yapo. Circle = ribeirão Atlântico, município de Mandaguaçu; triangle = ribeirão Uraí, mun. Londrina; lozenge $=$ rio Fortaleza, mun Tibagi; and star $=$ rio Verde, mun. Ponta Grossa, Paraná State. 
the gel using Whatman $3 \mathrm{MM} \circledast$ paper wicks (4 $\mathrm{mm} \times 8 \mathrm{~mm})$ soaked with the samples, which were submitted to continuous horizontal electrophoresis, under cooling. The gels were prepared with $15 \mathrm{~g} \%$ of corn starch (Val et al., 1981). Two buffer solutions were used: Tris $0.135 \mathrm{M} / \mathrm{Citric}$ acid $0.043 \mathrm{M}$ pH 7.0 (TC), Tris 0.18M/Boric acid 0.1/EDTA 0.004M pH 8.6 (TBE). The gel was made with TC diluted 1:15 and TBE diluted 1:4. A voltage gradient of $250 \mathrm{~V}$ was applied for 16 hours for $\mathrm{TC}$ buffer, and $450 \mathrm{~V}$ for TBE buffer.

After electrophoresis, the gel was horizontally sliced length-wise into two slabs, which were incubated with spe- cific staining solutions according to Murphy et al., (1996). Fifteen enzyme systems were analyzed, which allowed the detection of 24 loci. The interpretation of the enzyme genetic patterns was based on quaternary structure described by Ward et al. (1992). The allele and loci designation followed the International Union of Biochemistry and Molecular Biology (1992) nomenclature. The genetic variability was estimated using the average heterozygosity of Nei (1978) (He and $\mathrm{Ho}$ ). The homogeneity of the allelic frequencies between the populations was verified through a contingency chisquared test. The unbiased genetic identity (I) and genetic
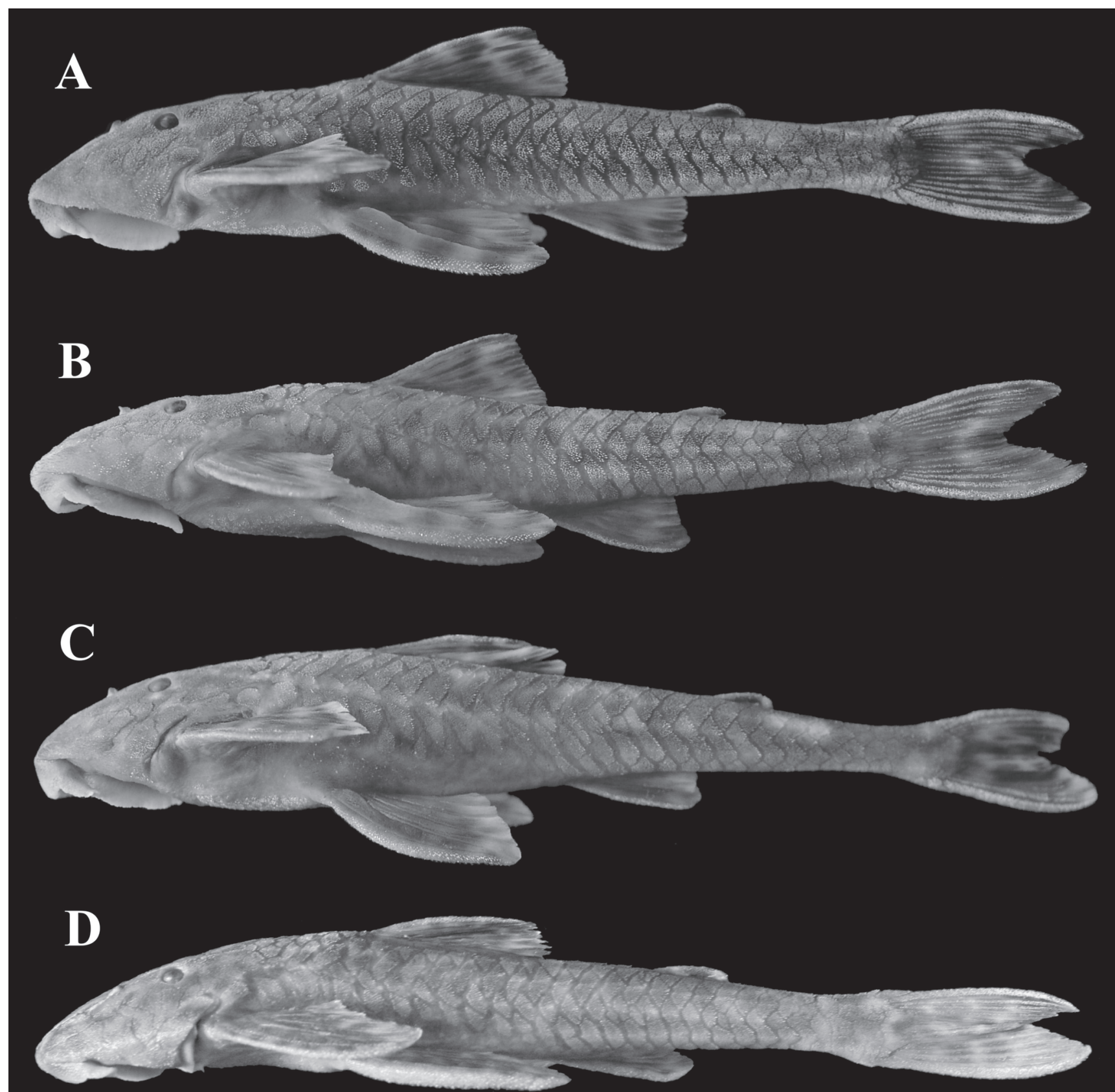

Fig. 2. Lateral view of four specimens of Neoplecostomus yapo from the following localities: A, ribeirão Atlântico, $85.9 \mathrm{~mm}$ SL; B) ribeirão Uraí, $93.3 \mathrm{~mm}$ SL; C) rio Verde, $96.0 \mathrm{~mm} \mathrm{SL}$; and D) rio Fortaleza, $97.4 \mathrm{~mm}$ SL (type locality of N. yapo). 
distance (D) were calculated following Nei (1978). All of the estimates were calculated using the software POP GENE 1.31 (Yeh \& Boyle, 1997).

\section{Results}

The electrophoretic banding pattern was similar to that described by Zawadzki et al. (2004) in N. paranensis. Twentyfour loci were detected, but only two $(8.3 \%)$ exhibited polymorphism ( $G p i-A$ and $G d h$ ) in the rio Verde sample and two $(8.3 \%)$ in the rio Fortaleza (Gpi-A and Gpi-B) sample. The

Table 1. Allelic frequencies per locus of Neoplecostomus yapo de from four localities in the rio Paranapanema basin. Polymorphic loci in bold. $\mathrm{Ho}=$ observed heterozygosity; $\mathrm{He}$ = expected heterozygoisty; $\mathrm{SD}=$ standard deviation; $\mathrm{Ae}=$ mean number of alleles per locus; $\mathrm{P}=$ proportion of polymorphic loci.

\begin{tabular}{|c|c|c|c|c|c|}
\hline Locus & allele & $\begin{array}{c}\text { rio } \\
\text { Verde }\end{array}$ & $\begin{array}{c}\text { rio } \\
\text { Fortaleza }\end{array}$ & $\begin{array}{c}\text { ribeirão } \\
\text { Uraí }\end{array}$ & $\begin{array}{c}\text { ribeirão } \\
\text { Atlântico }\end{array}$ \\
\hline Aat-1 & $a$ & 1.0000 & 1.0000 & 1.0000 & 1.0000 \\
\hline Aat-2 & $a$ & 1.0000 & 1.0000 & 1.0000 & 1.0000 \\
\hline$A c p$ & $a$ & 1.0000 & 1.0000 & 1.0000 & 1.0000 \\
\hline$A d h$ & $a$ & 1.0000 & 1.0000 & 1.0000 & 1.0000 \\
\hline Est & $a$ & 1.0000 & 1.0000 & 1.0000 & 1.0000 \\
\hline Gdh & $\begin{array}{l}a \\
b\end{array}$ & $\begin{array}{l}0.9000 \\
0.1000\end{array}$ & 1.0000 & 1.0000 & 1.0000 \\
\hline G3pd-1 & $a$ & 1.0000 & 1.0000 & 1.0000 & 1.0000 \\
\hline G3pd-2 & $a$ & 1.0000 & 1.0000 & 1.0000 & 1.0000 \\
\hline G6pd & $a$ & 1.0000 & 1.0000 & 1.0000 & 1.0000 \\
\hline \multirow[t]{3}{*}{ Gpi-A } & $a$ & 0.0500 & 0.2167 & & \\
\hline & $b$ & $\mathbf{0 . 0 3 5 7}$ & 0.0333 & & \\
\hline & $c$ & 0.1000 & 0.7500 & 1.0000 & 1.0000 \\
\hline \multirow[t]{2}{*}{$G p i-b$} & $a$ & & 0.0167 & & \\
\hline & $b$ & 1.0000 & 0.9833 & 1.0000 & 1.0000 \\
\hline$I d h-1$ & $a$ & 1.0000 & 1.0000 & 1.0000 & 1.0000 \\
\hline$I d h-2$ & $a$ & 1.0000 & 1.0000 & 1.0000 & 1.0000 \\
\hline$L d h-A$ & $a$ & 1.0000 & 1.0000 & 1.0000 & 1.0000 \\
\hline$L d h-B$ & $a$ & 1.0000 & 1.0000 & 1.0000 & 1.0000 \\
\hline$M d h-A$ & $a$ & 1.0000 & 1.0000 & 1.0000 & 1.0000 \\
\hline$M d h-B$ & $a$ & 1.0000 & 1.0000 & 1.0000 & 1.0000 \\
\hline$M d h-C$ & $a$ & 1.0000 & 1.0000 & 1.0000 & 1.0000 \\
\hline$M e-1$ & $a$ & 1.0000 & 1.0000 & 1.0000 & 1.0000 \\
\hline$M e-2$ & $b$ & 1.0000 & 1.0000 & 1.0000 & 1.0000 \\
\hline Per-1 & $a$ & 1.0000 & 1.0000 & 1.0000 & 1.0000 \\
\hline Per-2 & $a$ & 1.0000 & 1.0000 & 1.0000 & 1.0000 \\
\hline Pgm & $a$ & 1.0000 & 1.0000 & 1.0000 & 1.0000 \\
\hline \multirow[t]{7}{*}{ Sod } & $a$ & 1.0000 & 1.0000 & 1.0000 & 1.0000 \\
\hline & Ho & 0.0042 & 0.0111 & 0.0000 & 0.0000 \\
\hline & SD & 0.0204 & 0.0478 & 0.0000 & 0.0000 \\
\hline & $\mathrm{He}$ & 0.0195 & 0.0179 & 0.0000 & 0.0000 \\
\hline & SD & 0.0674 & 0.0808 & 0.0000 & 0.0000 \\
\hline & $\mathrm{Ae}$ & 1.0242 & 1.0280 & 1.0000 & 1.0000 \\
\hline & P & $8.33 \%$ & $8.33 \%$ & 0.0000 & 0.0000 \\
\hline
\end{tabular}

Table 2. Identity (above diagonal) and genetic distance (bellow diagonal) of Nei (1978) among four samples of Neoplecostomus yapo from the rio Paranapanema basin.

\begin{tabular}{ccccc}
\hline \multirow{2}{*}{ Sample } & $\begin{array}{c}\text { 1. rio } \\
\text { Verde }\end{array}$ & $\begin{array}{c}\text { 2. rio } \\
\text { Fortaleza }\end{array}$ & $\begin{array}{c}\text { 3. ribeirão } \\
\text { Uraí }\end{array}$ & $\begin{array}{c}\text { 4. ribeirão } \\
\text { Atlântico }\end{array}$ \\
\hline 1 & $* * * *$ & 0.9990 & 0.9991 & 0.9991 \\
2 & 0.0010 & $* * * *$ & 0.9978 & 0.9978 \\
3 & 0.0009 & 0.0022 & $* * * *$ & 1.0000 \\
4 & 0.0009 & 0.0022 & 0.0000 & $* * * *$ \\
\hline
\end{tabular}

other two samples did not show any polymorphism in the surveyed loci.

Table 1 shows the allelic frequencies for the 24 loci to the specimens from each locality and the genetic variability measures. Table 2 shows the genetic identity and distance values of Nei (1978). The values from Table 1 indicate that the samples present low genetic variability. Table 3 shows the Wright's statistics for population structure (Wright, 1978) and the result of homogeneity qui square test for allele frequencies.

\section{Discussion}

In this work, no allozymic species-specific marker was found for the four analyzed samples. This result is significant when compared to the works cited above where specific markers are often found for Neotropical close-related fish species, especially for the family Loricariidae. The results of the present work become even more apparent when compared with those obtained by Zawadzki et al. (2004a) that found 12 diagnostic loci on 22 examined for a sample of Neoplecostomus corumba (Neoplecostomus sp. in that work) from the rio Corumbá, rio Paranaíba basin (Caldas Novas, GO) and $N$. paranensis from the córrego Hortelã, rio Pardo basin (Botucatu, SP). These authors found a zero heterozygosity (no heterozygote in the surveyed loci), and linked these values to a small population size, narrow geographical distribution and limited gene flow to some nearby population.

These small-lengthened species inhabit headwater streams, small to medium streams, usually in shallow rapids and well-oxygenated waters in the southeastern Neotropical region. Therefore, some biological requirements should reduce dispersion, since Neoplecostomus species are not caught in the beds of major rivers and have, apparently, a fragmented distribution. Ferraris Jr. (2003) highlighted that species of Neoplecostomus are still little known and few data have been published about them besides its original descriptions. Thus, understanding the genetic structure population of such species, such as $N$. yapo, could provide access to the degree of isolation of these populations. In addition, parameters such as gene flow, inbreeding coefficients and genetic variability of the population could be used for management programs of threatened populations or environments as well as for biogeographic studies of aquatic organisms.

The $F_{\text {IS }}$ and $F_{\text {IT }}$ values measure the heterozygote deficiency in each population and in the whole population, respectively. The $F_{\text {IS }}$ and $F_{\text {IT }}$ values obtained in this work indicate a heterozygote deficiency for $G d h$ and $G p i-A$ loci and a heterozygote excess for Gpi-B locus. $F_{\mathrm{ST}}$ value measures the differentiation among the populations. According to Wright (1978), values of $F_{\mathrm{ST}}$ below 0.05 indicate a low differentiation between populations, values between 0.05 and 0.15 reveal a moderate differentiation, and values above 0.25 can be considered indicative of a great genetic differentiation Thus, according to Wright's criterion, the average $F_{\text {IS }}=0.5181$, 
Table 3. Wright's statistics for the four samples of Neoplecostomus yapo from the rio Paranapanema basin. $\mathrm{P}$ is the probability of homogeneity qui-square test.

\begin{tabular}{cccccc}
\hline Locus & Sample size & $\mathrm{F}_{\mathrm{IS}}$ & $\mathrm{F}_{\mathrm{IT}}$ & $\mathrm{F}_{\mathrm{ST}}$ & $\mathrm{P}$ \\
\hline Aat -1 & 70 & $* * * *$ & $* * * *$ & 0.0000 & 1.0000 \\
Aat -2 & 70 & $* * * *$ & $* * * *$ & 0.0000 & 1.0000 \\
Acp & 70 & $* * * *$ & $* * * *$ & 0.0000 & 1.0000 \\
Adh & 70 & **** & $* * * *$ & 0.0000 & 1.0000 \\
Est & 70 & $* * * *$ & $* * * *$ & 0.0000 & 1.0000 \\
Gdh & 67 & 1.0000 & 1.0000 & 0.0769 & 0.009 \\
G3pd-1 & 70 & $* * * *$ & $* * * *$ & 0.0000 & 1.0000 \\
G3pd-2 & 70 & $* * * *$ & $* * * *$ & 0.0000 & 1.0000 \\
G6pd & 70 & $* * * *$ & $* * * *$ & 0.0000 & 1.0000 \\
Gpi-A & 70 & 0.4907 & 0.5482 & 0.1130 & 0.001 \\
Gpi-B & 70 & -0.0169 & -0.0042 & 0.0126 & 0.719 \\
Idh-1 & 70 & $* * * *$ & $* * * *$ & 0.0000 & 1.0000 \\
Idh-2 & 70 & $* * * *$ & $* * * *$ & 0.0000 & 1.0000 \\
Ldh-A & 70 & $* * * *$ & $* * * *$ & 0.0000 & 1.0000 \\
Ldh-B & 70 & $* * * *$ & $* * * *$ & 0.0000 & 1.0000 \\
Mdh-A & 70 & $* * * *$ & $* * * *$ & 0.0000 & 1.0000 \\
Mdh-B & 70 & $* * * *$ & $* * * *$ & 0.0000 & 1.0000 \\
Mdh-C & 70 & $* * * *$ & $* * * *$ & 0.0000 & 1.0000 \\
Me-1 & 70 & $* * * *$ & $* * * *$ & 0.0000 & 1.0000 \\
Me-2 & 70 & $* * * *$ & $* * * *$ & 0.0000 & 1.0000 \\
Per-1 & 70 & $* * * *$ & $* * * *$ & 0.0000 & 1.0000 \\
Per -2 & 70 & $* * * *$ & $* * * *$ & 0.0000 & 1.0000 \\
Pgm & 70 & $* * * *$ & $* * * *$ & 0.0000 & 1.0000 \\
Sod & 70 & $* * * *$ & $* * * *$ & 0.0000 & 1.0000 \\
\hline Mean & 70 & 0.5181 & 0.5681 & 0.1039 & \\
\hline & & & &
\end{tabular}

$F_{\text {IT }}=0.5681$ values show that there is a heterozygote deficiency in the polymorphic loci. The average $F_{\mathrm{ST}}=0.1039$ (Table 3) value and the genetic distance values (Table 2) indicate that the four samples are genetically very similar to each other, with moderate genetic differentiation.

Rare works address the genetics of small-sized fishes (and hence, non-commercial) from small streams in the neotropics. Estimates of genetic variability, as the mean expected heterozygosity, the rates of enzymatic polymorphism and genetic distance and similarity between populations are important contributions in the field of conservation, biogeography and taxonomy of these populations. The values presented in Table 1 indicate that this species has low genetic variability as most loricariid species studied so far. We believe that this low variability is probably due to sedentary habits of this species, which leads to inbreeding.

In the Neotropical region, allozymic studies addressing co-specific populations are limited to a few works such as Revaldaves et al. (1997) on the genetic variation of populations of Prochilodus lineatus (Characidae) from the rio Paraná basin; Zawadzki et al. (2002) on two populations of Hypostomus margaritifer (Loricariidae) from the upper rio Paraná basin, and Zawadzki et al. (2008b) on three populations of Hypostomus regani (Loricariidae) from reservoirs of Manso (rio Paraguay basin) and the Itaipu and Corumbá (both in the upper rio Paraná basin). But none of these works dealt on species from small streams.

The results obtained herein showed that the four analyzed samples belong to the same species, $N$. yapo and that they present low genetic variability. In addition, the data enabled to investigate a hypothesis which arose when Zawadzki et al. (2004a) obtained the aforementioned 12 allozymic markers on 22 analyzed loci. Due to the high number of genetic markers and to the close morphological similarity described by those authors, one could argue the use of allozyme markers as a good tool to discriminate species of Neoplecostomus. The questioning could arise because the relative isolated distribution of Neoplecostomus populations in headwaters could generate exclusive fixed alleles for most of the partially isolated populations. What was achieved here shows that it would not be true, at least, for the analyzed samples of $N$. yapo.

Considering the specimens in Fig. 2 and specimens deposited in the ichthyological collection of Nupélia (NUP 5156, NUP 3560, NUP 4747, and NUP 5156) we observed, besides being subtle, some morphological divergence between the specimens of the four samples. For example, as in Fig. 2, the specimen from rio Verde shows a considerably smaller caudal peduncle height, but this difference is diluted in an analysis with several specimens from each location $(\mathrm{CH}$ Zawadzki, unpublished data). Still in Fig. 2, the concave dorsalfin distal margin of the specimen from the ribeirão Atlântico contrasts to the straight dorsal-fin distal margin on the ribeirão Uraí specimen. Subtle morphological differences are expected between populations of species distributed in sharply regions (falls, waterfalls, rapids) which could somehow generate barriers to free dispersal.

Theoretically, these morphological differences should be reflected in a more polymorphic molecular marker, but they were not in the allozymic markers. These data show that individuals belonging to a species of Neoplecostomus, even presenting a relative geographical distribution, can have a strong similarity of the dominant alleles in most surveyed loci.

\section{Acknowledgements}

Authors thank to Claudenice Deitós and Horácio F. Júlio Jr. for reviewing the manuscript and useful suggestions; to Alessandro G. Bifi, Américo M. Neto, Aparecido de Souza, Edson S. da Silva, Mário B. Loyola, Wanner Galves and William M. Ohara, for helping in the field work; to Ana Carolina F. Lacerda for helping with the English language; to Nupélia for the logistic support; and to Corn Products Brazil for providing penetrose 50 . This work was granted by the $\mathrm{MCT} / \mathrm{CNPq}$ (Ministério da Ciência e Tecnologia/Conselho Nacional de Desenvolvimento Científico e Tecnológico) - Edital Universal, protocol number 484716-2006-9.

\section{Literature Cited}

Almeida, L. F. \& L. M. K. Sodré. 1998. Analysis of genetic variability in three species of Pimelodidade (Ostariophysi - Siluriformes). Genetics and Molecular Biology, 21: 487-492.

Buth, D. G. 1984. The application of electrophoretic data in systematic studies. Annual Review of Ecology and Systematics, 15: 501-522. 
Ferraris Jr., C. J. 2003. Subfamily Neoplecostominae. Pp. 319-320. In: Reis, R. E.; Kullander, S. O. \& Ferraris Jr., C. J. (Eds.). Check list of the freshwater fishes of South and Central America. Porto Alegre, EDIPUCRS.

Fisch-Muller, S., R. Mazzoni \& C. Weber. 2001. Genetic and morphological evidences for two new sibling species of Ancistrus (Siluriformes: Loricariidae) in upper Rio Tocantins drainage, Brazil. Ichthyological Exploration of Freshwaters, 12: 289-304.

International Union of Biochemistry and Molecular Biology. 1992. Nomenclature Commitee (1992) Enzyme Nomenclature. San Diego, Academic Press.

Langeani, F. 1990. Revisão do gênero Neoplecostomus Eigenmann \& Eigenmann, 1888, com a descrição de quatro novas espécies do sudeste brasileiro (Ostariophysi, Siluriformes, Loricariidae). Comunicações do Museu de Ciências PUCRS, série Zoologia, 3: 3-31.

Murphy, R. W., J. W. Sites Jr., D. G. Buth \& C. H. Haufler. 1996. Poteins: Isozyme electrophoresis. Pp. 51-120. In: Hillis, D. M., C. Moritz \& B. K. Mable (Eds.). Molecular Systematics. Sunderland, Sinnauer Assoc.

Nei, M. 1978. Estimation of average heterozygosity and genetic distance from a small number of individuals. Genetics, 89: 583-590.

Paiva, S., E. Renesto \& C. H. Zawadzki. 2005. Genetic variability of Hypostomus (Teleostei: Loricariidae) from the Ribeirão Maringá, a stream of the upper Rio Paraná basin, Brazil. Genetics and Molecular Biology, 28: 370-375.

Pasteur, N., G. Pasteur, F. Bonhomme, J. Catalan \& J. BrittonDavidian. 1988. Practical Isozyme Genetics. Ellis Horwood, Chichester, 215p.

Peres, D. P., E. Renesto, A. S. Lapenta \& C. H. Zawadzki. 2002. Genetic variability in Hoplias malabaricus (Osteichthyes: Erythrinidae) in fluvial and lacustrine environments in the upper Paraná river floodplain (Paraná State, Brazil). Biochemical Genetics, 40: 209-223.

Reis, R. E. \& E. H. L. Pereira. 2000. Three new species of the loricariid catfish genus Loricariichthys (Teleostei: Siluriformes) from southern South America. Copeia, 2000: 1029-1047.

Renesto, E. \& C. H. Zawadzki. 1997. Taxonomia bioquímica de Astyanax do reservatório de Segredo. Pp. 85-96. In: Agostinho, A. A. \& L. C. Gomes (Eds.). Reservatório de Segredo: bases ecológicas para o manejo. Maringá, EDUEM.

Renesto, E., C. H. Zawadzki \& E. Revaldaves. 2000. Genetic evidence for two species of the genus Pimelodus Lacépède, 1803 (Siluriformes, Pimelodidae) in the Iguaçu River (Brazil). Genetics and Molecular Biology, 23: 809-813.

Renesto, E., C. H. Zawadzki \& E. Revaldaves. 2001. Biochemical Taxonomy of Crenicichla (Pisces: Perciformes: Cichlidae) of the Iguaçu River, Brazil. Brazilian Archives of Biology and Technology, 44: 15-22.

Revaldaves, E., E. Renesto \& M. F. P. S. Machado. 1997. Genetic variability of Prochilodus lineatus (Characiformes: Prochilodontidae) in the upper Paraná river. Revista Brasileira de Genética, 20: 381-388.

Val, A. L., A. R. Schwantes, M. L. B. Schwantes \& P. H. de Luca. 1981. Amido hidrolisado de milho como suporte eletroforético. Ciência e Cultura, 33: 737-741.

Ward, R. D., D. O. F. Skibinski \& M. Woodward. 1992. Protein heterozygosity, protein structure, and taxonomic differentiation. Evolutionary Biology, 26: 73-157.

Yeh, F. C. \& T. J. B. Boyle. 1997. Population genetic analysis of codominant and dominant markers and quantitative traits. Belgian Journal of Botany, 129: 156-157
Wright, S. 1978. Evolution and the Genetics of Populations. Vol 4. Chicago, The University of Chicago Press, 580p.

Zawadzki, C. H. 2001. Sistemática e variação aloenzimática da família Loricariidae (Teleostei: Siluriformes) dos reservatórios de Corumbá e Itaipu, na bacia do alto rio Paraná, Brasil. Maringá, 2001. Unpublished Ph.D. Dissertation, Universidade Estadual de Maringá, Maringá, 71p.

Zawadzki, C. H., A. L. Alves, E. Renesto \& C. Oliveira. 2004a. Biochemical evidence of a possible new species of Neoplecostomus (Teleostei: Loricariidae) from the upper Rio Paraná basin, Brazil. Biochemical Systematics and Ecology, 32: 573-582.

Zawadzki, C. H., M. F. P. S. Machado \& E. Renesto. 2001. Differential expression for tissue-specific isozymes in three species of Hypostomus Lacépède, 1803 (Teleostei: Loricariidae). Biochemical Systematics and Ecology, 29: 911-922.

Zawadzki, C. H., C. S. Pavanelli \& F. Langeani. 2008 a. Neoplecostomus (Teleostei: Loricarridae) from the upper Paraná river basin, with description of three new species. Zootaxa, 1757: 31-48.

Zawadzki, C. H., C. S. Pavanelli \& C. Weber. 2002. Morphological and biochemical comparison of two allopatrid populations of Hypostomus margaritifer (Regan, 1907) (Osteichthyes: Loricariidae) from the upper Paraná River basin, Brazil. Acta Scientiarum, 24: 499-505.

Zawadzki, C. H., R. E. Reis \& E. Renesto. 2000. Allozyme discrimination of three species of Loricariichthys (Siluriformes: Loricariidae) from Southern Brazil. Revue suisse de Zoologie, 107: 663-674.

Zawadzki, C. H., E. Renesto \& L. M. Bini. 1999. Genetic and morphometric analysis of three species of the genus Hypostomus Lacépède, 1803 (Osteichthyes: Loricariidae) from the Rio Iguaçu basin (Brazil). Revue suisse de Zoologie, 106: 91-105.

Zawadzki, C. H., E. Renesto, S. Paiva \& M. C. S. Lara-Kamei. 2004b Allozyme differentiation of four populations of Hypostomus (Teleostei: Loricariidae) from Ribeirão Keller, a stream in the upper Rio Paraná basin, Brazil. Genetica, 121: 251-257.

Zawadzki, C. H., E. Renesto, M. D. Peres \& S. Paiva. 2008 b. Allozyme variation among three populations of the armored catfish Hypostomus regani (Ihering, 1905) (Siluriformes, Loricariidae) from the Paraná and Paraguay River basins, Brazil. Genetics and Molecular Biology, 31: 767-771.

Zawadzki, C. H., E. Renesto, R. E. Reis, M. O. Moura \& R. P. Mateus. 2005. Allozyme relationships in hypostomines (Teleostei: Loricariidae) from the Itaipu Reservoir, upper Paraná river basin, Brazil. Genetica, 123: 271-283.

Zawadzki, C. H., C. Weber \& C. S. Pavanelli. 2008c. Two new species of Hypostomus Lacépède (Teleostei: Loricariidae) from the upper rio Paraná basin, Brazil. Neotropical Ichthyology, 6: 403-412.

Accepted February 2009

Published March 31, 2009 